\title{
The surface deformation of the 2020 Doğanyol-Sivrice earthquake (Mw 6.8) and the earlier events suggest $M w<7.0$ earthquakes do not create significant surface slip along the East Anatolian Fault Zone
}

\author{
Kenan Akbayram ${ }^{1,2}$, Kemal Kıranşan ${ }^{1,3}$, Çağlar Özer ${ }^{4}$, Sadık Varolgüneş ${ }^{1,2}$ \\ ${ }^{1}$ Centre for Energy, Environment and Natural Disasters, Bingöl University, 12000 Bingöl, \\ Turkey \\ ${ }^{2}$ Faculty of Engineering and Architecture, Department of Civil Engineering, Bingöl \\ University, 12000 Bingöl, Turkey \\ ${ }^{3}$ Faculty of Arts and Science, Department of Geography, Bingöl University, 12000 Bingöl, \\ Turkey \\ ${ }^{4}$ Earthquake Research Centre, Ataturk University, 25240 Erzurum, Turkey
}

*Corresponding author: kakbayram@gmail.com, kakbayram@bingol.edu.tr

This is a non-peer reviewed pre-print submitted to EarthArXiv. This paper has been submitted to Tectonophysics for review. 


\section{ABSTRACT}

2 The $2020 \mathrm{Mw}$ 6.8 Doğanyol-Sivrice earthquake occurred on the Pütürge Segment of the

3 left-lateral East Anatolian Fault Zone (EAFZ). Our field investigation within 6 weeks after the

4 earthquake suggests the following results. (1) The 2020 earthquake created a 54-km-long

5 surface deformation zone along the Pütürge Segment. (2) No co-seismic surface slip has been

6 formed after the earthquake. (3) The deformation zone consisted of intense ground fissures, rock

7 falls, landslides, liquefaction of various lengths mostly occurred along fault traces mapped in

8 previous active fault investigations. When we have evaluated our field findings together with the

9 previous historical and instrumental earthquake data the following results on the long-term

10 behavior of the EAFZ have been determined. The significant co-seismic offset (between 2.0 and

114.5 meters) only forms when the earthquake magnitudes reach to Mw 7.0 along the EAFZ. In the

12 last 160 years, $~ 300$-km-long part of the EAFZ ruptured with 7 major earthquakes $(6.7 \leq \mathrm{Ms} \leq 7.2)$.

13 The $\sim 130-\mathrm{km}$-long part of the EAFZ still remains as seismic gap. Here we name two most

14 important seismic gaps of the EAFZ as the Kahramanmaraş and the Bingöl Seismic Gaps.

15 Keywords 2020 Doğanyol-Sivrice earthquake, Active plate boundary, East Anatolian Fault

16 Zone (EAFZ), Co-seismic slip, Seismic Gap. 


\section{Highlights}

- The 2020 Doğanyol-Sivrice earthquake (Mw 6.8) occurred on the Pütürge Segment of the left-lateral East Anatolian Fault Zone (EAFZ).

- The earthquake created a 54-km-long surface deformation zone.

- No co-seismic surface slip has been formed after the earthquake.

- Evaluation of our field findings together with the previous historical/instrumental earthquake data the following results on the long-term behavior of the EAFZ have been determined.

- The significant co-seismic offset (between 2.0 and 4.5 meters) only forms when the earthquake magnitudes reach to Mw 7.0 along the EAFZ.

- The $130-\mathrm{km}$-long part of the EAFZ still remains as seismic gap. 
1 The surface deformation of the 2020 Doğanyol-Sivrice

2 earthquake ( $\mathrm{Mw}$ 6.8) and the earlier events suggest $\mathrm{Mw}<7.0$

3 earthquakes do not create significant surface slip along the East

4 Anatolian Fault Zone

$5 \quad$ Kenan Akbayram ${ }^{1,2}$

$6 \quad{ }^{1}$ Centre for Energy, Environment and Natural Disasters, Bingöl University, 12000 Bingöl,

7 Turkey

$8 \quad{ }^{2}$ Faculty of Engineering and Architecture, Department of Civil Engineering, Bingöl

9 University, 12000 Bingöl, Turkey

10 e-mail: kakbayram@gmail.com, akbayram@itu.edu.tr

11 Phone number: +90 5323308189

12 Kemal Kıranşan ${ }^{1,3}$

$13{ }^{1}$ Centre for Energy, Environment and Natural Disasters, Bingöl University, 12000 Bingöl,

14 Turkey

$15{ }^{3}$ Faculty of Arts and Science, Department of Geography, Bingöl University, 12000 Bingöl,

16 Turkey

17 Çă̆lar Özer ${ }^{4}$

$18{ }^{4}$ Earthquake Research Centre, Ataturk University, 25240 Erzurum, Turkey

19 Sadık Varolgüneş ${ }^{1,2}$

$20{ }^{1}$ Centre for Energy, Environment and Natural Disasters, Bingöl University, 12000 Bingöl,

21 Turkey

$22 \quad{ }^{2}$ Faculty of Engineering and Architecture, Department of Civil Engineering, Bingöl

23 University, 12000 Bingöl, Turkey 


\section{ABSTRACT}

The 2020 Mw 6.8 Doğanyol-Sivrice earthquake occurred on the Pütürge Segment of the left-lateral East Anatolian Fault Zone (EAFZ). Our field investigation within 6 weeks after the earthquake suggests the following results. (1) The 2020 earthquake created a 54-km-long surface deformation zone along the Pütürge Segment. (2) No co-seismic surface slip has been formed after the earthquake. (3) The deformation zone consisted of intense ground fissures, rock falls, landslides, liquefaction of various lengths mostly occurred along fault traces mapped in previous active fault investigations. When we have evaluated our field findings together with the previous historical and instrumental earthquake data the following results on the long-term behavior of the EAFZ have been determined. The significant co-seismic offset (between 2.0 and 4.5 meters) only forms when the earthquake magnitudes reach to Mw 7.0 along the EAFZ. In the last 160 years, $~ 300-\mathrm{km}$-long part of the EAFZ ruptured with 7 major earthquakes $(6.7 \leq \mathrm{Ms} \leq 7.2)$. The $\sim 130-\mathrm{km}$-long part of the EAFZ still remains as seismic gap. Here we name two most important seismic gaps of the EAFZ as the Kahramanmaraş and the Bingöl Seismic Gaps.

41 Keywords 2020 Doğanyol-Sivrice earthquake, Active plate boundary, East Anatolian Fault 42 Zone (EAFZ), Co-seismic slip, Seismic Gap.

\section{INTRODUCTION}

The left-lateral strike-slip East Anatolian Fault Zone (EAFZ), the active plate boundary between the Anatolian and Arabian lithospheric plates, extends for $\sim 430 \mathrm{~km}$ in NE-SW direction between Karlıova (Bingöl) and Kahramanmaraş (Fig. 1A-1B) (Şengör, 1979; Reilinger and McClusky, 2011). The EAFZ connects with the North Anatolian Fault Zone (NAFZ) in Karlıova (Bingöl, Turkey) (Şengör, 1979; Şaroğlu, 1985; Şengör et al., 1985) and with the Dead Sea Fault Zone (DSFZ) near Kahramanmaraş (Turkey) (Fig. 1A) (McKenzie, 1976; Karig and Kozlu, 1990; Perinçek and Çemen, 1990; Westaway \& Arger 1996; Westaway, 2003). The left-lateral EAFZ and the right-lateral NAFZ together accommodate the westward escape of the Anatolian 52 plate (McKenzie, 1972; Şengör, 1979).

An Mw 6.8 earthquake occurred on the Pütürge Segment (cf. Duman and Emre, 2013) of 54 the EAFZ (Fig. 1B) (Şengör, 1979; Reilinger and McClusky, 2011) between the Doğanyol 55 (Malatya) and the Sivrice (Elazığ) districts at 17:55:11 UTC (20:55:11 local time) on 24 January 562020 (hereafter referred to as the 2020 earthquake). The main shock focus is estimated at 
approximately $6 \mathrm{~km}$ northeast of Doğanyol, Malatya $\left(39.0630^{\circ} \mathrm{E}-38.3593^{\circ} \mathrm{N}\right)($ Figs. 1B) at $\sim 8$

$58 \mathrm{~km}$ depth (Pousse-Beltran et al., 2020). Severe damages to houses, infrastructures were occurred not only along the rupture zone but also in the Elazığ city center, approximately $30 \mathrm{~km}$ north of the rupture zone. According to the Ministry of Interior Disaster and Emergency Management

61 Presidency of Turkey (AFAD), the 2020 earthquake caused the killing of 41 people, injuring of

$62 \sim 1600$ others, destruction of 381 houses, heavy damage on 3.379 houses, medium and minor 63 damage on 5508 houses.

In this paper, we present (1) the results of a field survey held within 6 weeks of the mainshock to clarify the characteristics of rupture associated with the seismic activity and (2) the seismic data collected prior and after the 2020 earthquake along the rupture zone. It is crucial to record field data of surface deformation immediately after the event since they rapidly disappear due to human activities and erosion by rainfall. Defining the extent of rupture and the sense of shear is important for the understanding of future disasters.

We have also evaluated our field findings with the previously published data on major earthquakes (Ms $\geq 6.8$ ) that occurred along the EAFZ in the last 160 years. Our evaluation suggests a relationship between the earthquake magnitudes and the formation of co-seismic surface slip along the EAFZ and has also given some new results on the long-term behavior of 74 the EAFZ.

\section{OUTLINE OF THE EAST ANATOLIAN FAULT ZONE}

Following the partly description of the EAFZ (Altınl1, 1963) its transform fault nature first recognized by Allen (1969). The destructive May 22, 1971, Bingöl (Mw 6.8) earthquake (Seymen and Aydın, 1972) followed by first detail mapping of the EAFZ (Arpat and Şaroğlu, 1972). Since then, the seismicity of the EAFZ and its Quaternary evolution has been studied by several groups (Arpat and Şaroğlu, 1975; McKenzie, 1976, 1978; Jackson and McKenzie, 1984; Dewey et al., 1986; Muehlberger and Gordon, 1987; Westaway, 1994; Westaway and Arger, 1996; Reilinger et al., 2006; Reilinger and McClusky, 2011; Bulut et al., 2012; Duman and

83 Emre, 2013; Aktuğ et al., 2016; Yönlü et al., 2017; Khalifa et al., 2018). Although the formation 84 age of the EAFZ is still under debate, dating of the lignite brackets cropping-out along the fault 85 zone suggests that it is an active tectonic structure since the late Pliocene (Arpat and Şaroğlu, 86 1972; Hempton, 1985; Şengör et al., 1985; Dewey et al., 1986; Herece, 2008). Mapping of the 
87 offset of geological and geomorphic structures evidenced $15 \mathrm{~km}$ to $33 \mathrm{~km}$ of cumulative offset 88 along the EAFZ (Hempton, 1987; Westaway and Arger, 1996; Bulut et al., 2012). Consequently,

896 to $11 \mathrm{~mm} \mathrm{yr}^{-1}$ slip rate was calculated (Arpat and Şaroğlu, 1975; Herece and Akay, 1992;

90 Kiratzi, 1993; Westaway, 1994; Yürür and Chorowicz, 1998; Çetin et al., 2003; Aksoy et al.,

91 2007; Herece, 2008; Duman and Emre, 2013; Yönlü et al., 2013). Recent GPS studies provide a

92 similar slip rate of $\sim 10 \mathrm{~mm} \mathrm{yr}^{-1}$ along the EAFZ (Reilinger et al., 2006; Reilinger and McClusky,

93 2011; Mahmoud et al., 2013; Aktuğ et al., 2016). The segmented nature of the EAFZ has been

94 mapped by many studies (Arpat and Şaroğlu, 1972; Arpat and Şaroğlu, 1975; Hempton et al.,

95 1981; Muehlberger and Gordon, 1987; Barka and Kadinsky-Cade, 1988; Herece and Akay,

96 1992; Şaroğlu et al., 1992; Westaway, 1994; Herece, 2008; Duman and Emre, 2013). However,

97 there is still little consensus on the geometry and the lengths of its faults (or segments; cf. Duman

98 and Emre, 2013). In the present study, we use a simplified form of the detailed fault map

99 published by Duman and Emre (2013) as a base map (Figure 1B). Our simplified map does not

100 include the Sürgü-Misis Fault (SMF) system and the Amanos Segment (AS) of Duman and Emre

101 (2013). We exclude the SMF because it is not clear whether it is the northern strand of the EAFZ

102 as suggested by Duman and Emre (2013). We also exclude the AS because it is more likely a

103 fault that belongs to the Dead Sea Fault Zone (DSFZ) (cf., Perinçek and Çemen, 1990). In the

104 last 160 years, $\sim 300$-km-long part of the EAFZ ruptured with 7 major earthquakes $(6.7 \leq \mathrm{Ms} \leq 7.2)$

105 (Fig. 1B) that we discuss in detail in the following sections.

\section{3. METHODS}

The earthquake data presented in this section has been provided by the Ministry of

108 Interior Disaster and Emergency Management Presidency of Turkey (AFAD) that was collected

109 in SeisAN earthquake analysis software (Havskov and Ottemoller, 1999). Earthquake solutions

110 are redrawn from the Ministry of Interior Disaster and Emergency Management Presidency of

111 Turkey (AFAD) database and are projected over a $10 \mathrm{~m}$ resolution Digital Elevation Model

112 (DEM) prepared in ArcGIS software (Fig 2A-2B). DEM of the survey field area prepared from

113 the printed topographical maps. We geo-referenced the printed maps in ArcGIS Software, drawn

114 the contour curves, and digitized the maps. We then run 3D Analyses-Data Management-TIN-

115 Create TIN-TIN to Raster Module in ArcGIS Software to create DEM. 
Our field survey was conducted along the roads and rivers crossing the area with intense

117 deformation of ground surface and damage of constructions. We used DEM to ensure the

118 relationship between fissure distribution and geomorphological features. Information from the

119 local community has also guided us to identify the trace of coseismic deformation along the

120 survey area. We also used satellite imagery from Google Earth (updated 2019) for certain areas.

121 All images datasets were integrated into ArcGIS software. We adopted criteria for judgment if

122 fractures of ground surface are formed associated with the 2020 earthquake that has: (1) lateral

123 continuity, and (2) fresh appearance without erosion that indicate co-seismic ground fissures. We

124 measured orientation data of fractures (mainly strike and dip of the fracture planes) and width of

125 the deformation zone defined as the range in which ground is flexural deformed by conventional

126 instruments for field surveys such as a hand-held GPS receiver and geological compass.

\section{SEISMICITY ALONG THE PÜTÜRGE SEGMENT IN THE LAST 15 YEARS}

The 2020 earthquake occurred on the Pütürge Segment of the East Anatolian Fault Zone

129 (Figs. 1B and 2) which is a significant source of the regional seismic hazard (Ambraseys, 1989)

130 due to its long fault trace over $96 \mathrm{~km}$ (Duman and Emre, 2013). Before the 2020 earthquake, the

131 last major earthquakes on the Pütürge Segment occurred in 1874 (Ms 7.1), 1875 (Ms 6.7) and

1321905 (Ms 6.8) (Ambraseys, 1989).

133 Since the last major earthquake occurred on the EAFZ, prior to the 2020 earthquake, is

134 the 1971 Bingöl (Mw 6.8) earthquake (Fig. 1B) we concentrated on the seismic data reported

135 between 1970 and 2020 near and over the Pütürge Segment to give insight on the foreshock

136 activity. We realized that the most intense seismic activity before the mainshock occurred

137 between 2007 and 2019 along the Pütürge Segment (Table 1, Fig. 2A). The focal mechanism

138 solutions of the $M \geq 4.0$ earthquakes that occurred between 2007 and 2020 (Table 1) gives

139 predominantly left-lateral strike-slip mechanism with some minor vertical component in places

140 (Fig. 2A). The oblique solutions (Fig. 2A) are probably results of diffuse development of tearing

141 in the crust and small changes in the stress along secondary fault zones.

142 The focal mechanism solutions of the 2020 earthquake (Mw 6.8) and its $\mathrm{Mw} \geq 4.0$

143 aftershocks indicate almost pure strike-slip faulting (Table 2, Fig. 2B). The relocation of the

144 hypocenter of the mainshock (Pousse-Beltran et al., 2020) suggests that the earthquake occurred

145 at $8 \mathrm{~km}$ deep (Table 2, Fig. 2C). More than 3000 aftershocks between Mw 1.0 and Mw 5.1 are 
146

147

148

149

150

documented covering an area of $60 \mathrm{~km}$-long, $15 \mathrm{~km}$-wide and all of the aftershocks have occurred in the first $20 \mathrm{~km}$ of the crust (Fig 2C). This data well coincides with the relocated aftershock focal depths (7 to $17 \mathrm{~km}$ - Pousse-Beltran et al., 2020) and the results of an earthquake tomography study suggesting a maximum of $20 \mathrm{~km}$ depth for seismogenic zone along the EAFZ (Özer et al., 2019).

\section{RESULTS OF THE FIELD STUDY}

Despite its large magnitude, the 2020 earthquake was accompanied by no surface ruptures. In this section, we report the results of our field survey with insights on location, distribution, the orientation of the deformation associated with the 2020 earthquake (Table 3). We have mapped surface deformation for a distance over $54 \mathrm{~km}$ associated with the 2020 earthquake. The earthquake followed by significant liquefaction, landslides, rockfalls, pressure ridge, and fissure formations.

In the southwestern area, between Ormaniçi and Tosunlu villages (Pütürge, Malatya), the deformation zone associated with the 2020 earthquake does not always coincide with previously inferred faults (Fig. 3A). Instead, the deformation zone widens towards the northern part of the alluvial plain of the Mollahan Stream where new surface breaks formed over previously unmapped faults (the red lines in Fig. 3A). A pressure ridge with extensive ground fissures with a trend of N55E was observed over the cliffs at the south of the Mollahan Stream (location 1 in Fig. 3A and Table 3), approximately $30 \mathrm{~km}$ southwest of the epicenter (Fig. 3B). This is the southwesternmost co-seismic deformation structure we have mapped in our field study. The observed rockfalls and landslides on the northern side of this cliff and the extensive fissure formation also going towards the south indicate severe co-seismic damage around this pressure ridge. Another highly deformed area with major deep-reaching ground fissures (loc. 2 in Fig. 3A and Table 3) was observed at the north of the Mollahan Stream (Fig. 3C). Here, the deepreaching ground fissures can be interpreted as the faults bounding the asymmetric grabens of a small transtensional pull-apart basin, formed during the 2020 earthquake (Fig. 3C). This small pull-apart basin is a 50-meters-long and 7-meters-wide structure and the general trend of the ground fissures in this basin is N75E (Table 3), parallel to the main fault direction (Fig. 3A-3C). The most prominent liquefaction (loc. 4 in Fig. $3 \mathrm{~A}$ and Table 3 ) observed $4.2 \mathrm{~km}$ east of Ormaniçi (Fig. 3D) where one stream channel offset sinistrally about $1.6 \mathrm{~km}$ (Fig. 3A) with the 
176 historical earthquakes. We have visited this liquefaction area twice; (1) on 25 January 2020, the 177 day after the 2020 earthquake and, (2) on 4 May 2020. On 24 January 2020, we observed a 178 formation of a spherical crack with little sand eruption, discharges of spring, and sulfur smell 179 (Fig. 3D). During our second visit, on 4 May 2020, erupted sand and discharged spring water 180 seemed to be covered entire liquefaction area with a diameter of $\sim 10$ meters. Discharge of water 181 and gas (manifested by bubbles) was continuing at the site. In Tosunlu Village, $\sim 14 \mathrm{~km} \mathrm{SW}$ of 182 the epicenter, numbers of discontinuous ground fissures (loc. 5 in Fig. 3A and Table 3) whit a 183 general orientation of N70E (Fig. 3E) and severe damage of the houses were together observed. In the northeastern co-seismically damaged area, between Doğanyol (Malatya) and 186 previously inferred faults (Fig. 4A). Sivrice district stays at the northeastern tip of the deformation zone (Fig. 4A), we observed no deformation as we go further northeast. Destruction in Sivrice is very little however the Sivrice Mosque (loc. 19 in Fig. 4A and Table 3) is heavily damaged (Fig. 4B) $\left(38.448^{\circ} \mathrm{N}-39.309^{\circ} \mathrm{E}\right)$. That seems to be the result of low-quality construction as approved by the lack of lateral reinforcement binders in damaged load-bearing columns (Fig. 4C). Over the road in front of the Sivrice Mosque, we have observed N-S directed cracks 192 representing echelon cracks formed perpendicular to the main fault direction. In Sivrice, the 193 windows on the N-S directed walls of buildings were all broken. Towards the southwest, surface 194 deformation mainly represented by the gravitational cracks (Fig. 4C-4D) and ground fissures 195 with an average trend of N65E are formed concentrated in the zones of several tens of meters, 196 respectively (Fig. 4A and Table 3; locations 7, 8, 10, 13, and 15 to 18). The average direction of 197 the gravitational cracks (Table 3) coincides with the N60E direction of the Pütürge Segment 198 reported by Duman and Emre (2013). In some of these locations, sand eruption indicating 199 liquefaction accompanies the cracks (e.g., loc 14 in Table 3 and Fig. 4A). Between Akseki and 200 Sivrice, an approximately $4 \mathrm{~km}$ long area above the previously mapped active faults is severely 201 damaged (Fig. 4A and Table 3; locations 10 to 16). Along this area, co-seismically triggered 202 landslides (loc. 9), gravitational cracks with up to 40-50 cm downward movement (Fig. 4D; loc 203 13), overturned-damaged trees with up to $50 \mathrm{~cm}$ diameter (loc. 11) and severe damage on 204 telephone poles (Fig. 4E; loc 12) are together observed (for locations see Fig. 4A and Table 3). 205 Çevrimtaş Village (Sivrice, Elazığ) which stays only at $\sim 2 \mathrm{~km} \mathrm{NE}$ of the epicenter (Fig. 4A) is 206 one of the places that suffered the most damage in the 2020 earthquake. In this village, $90 \%$ of 
207 the houses were destroyed, two people were killed, 4 were injured and nearly 30 cattle also died.

208 The co-seismic faulting caused the formation of a pressure ridge just south of the Çevrimtaş

209 Village along the Karakaya Dam Lake that filled the Euphrates River Valley (Fig. 4F-4G; loc. 6

210 in Fig. 4A and Table 3). Over this pressure ridge, many cracks with an average N80E direction

211 were also formed (Fig. 4G). In Doğanyol (Malatya) which stays $\sim 3 \mathrm{~km}$ south of the epicenter

212 (Fig. 4A), we have also observed serious damage represented by intense ground fissures, rock

213 falls, landslides, destruction of houses and discharges of springs, during our field survey.

\section{6. DISCUSSION}

\section{5 \\ 6.1. RELATIONSHIP BETWEEN EARTHQUAKE MAGNITUDE AND CO-SEISMIC} SURFACE SLIP OF MAJOR SEISMIC EVENTS ALONG THE EAFZ

Along the EAFZ, major earthquakes $(6.7 \leq \mathrm{Ms} \leq 7.2)$ occurred during the historical and instrumental periods (Fig. 5; Table 4) (Pınar and Lahn, 1952; McKenzie, 1972; Jackson and McKenzie, 1984; Dewey et al., 1986; Ambraseys 1989; Guidoboni et al., 1994; Shebalin and Tatevossian, 1997; Ambraseys and Jackson 1998; Kondorskaya and Ulomov, 1999; Çetin et al., 2003; Taymaz et al., 1991; Tan et al., 2008; Kalafat et al., 2011). The historical earthquake record goes back to the $6^{\text {th }}$ century on the EAFZ (cf., Duman and Emre, 2013), however, for no time interval earlier than the $19^{\text {th }}$ century we confidently identify reliable earthquake data that

224 also includes observed fault lengths, and co-seismic surface slip measurements (cf., Duman and Emre, 2013). Thus, here we review the published data on major earthquakes $(\mathrm{Ms} \geq 6.7)$ that occurred along the EAFZ in the last 160 years. This review suggests a relationship between the earthquake magnitudes and the formation of co-seismic surface slip (Fig. 5; Table 3). We also plotted the time of these earthquakes vs their known ruptured fault length to show the position of major seismic gaps (Fig. 5B), that we also discuss here briefly.

The first major earthquake of the $19^{\text {th }}$ century accepted as the Ms 7.5, 1822 earthquake (Ambraseys and Jackson, 1998) that occurred at the southwestern part of the EAFZ (Fig. 5B)

232 (e.g., Duman and Emre, 2013). However, this earthquake occurred on the Amanos Segment of 233 the Duman and Emre (2013) which is the northernmost segment of the Dead Sea Fault Zone 234 (Fig. 5) (cf., Perinçek and Çemen, 1990). 
237 earthquake cycle of the EAFZ. According to the Duman and Emre (2013), the 1866 earthquake 238 caused rupture only on the Karliova Segment which is a 34-km-long fault. The length of the 239 Karliova segment is significantly shorter than the reported rupture length which is $45 \mathrm{~km}$ 240 (Ambraseys and Jackson, 1998; Nalbant et al., 2002). As we think of the other known 241 earthquakes with similar magnitudes (Table 3), the suggested $45 \mathrm{~km}$ rupture length seems more 242 compatible with the reported magnitude. Hence, we suggest approximately $10 \mathrm{~km}$ of the Ilica 243 Segment was also ruptured together with the Karlıova Segment during the 1866 earthquake (Fig. 244 5). A $3.5 \pm 0.1 \mathrm{~m}$ co-seismic offset formed during the 1866 earthquake (Table 4) (Herece, 2008). The 1866 earthquake followed by the Ms 7.1, 1874 earthquake occurred on the Palu 246 Segment (Fig. 5; Table 4) (Ambraseys, 1989; Ambraseys and Jackson 1998; Duman and Emre, 247 2013). The 1874 earthquake created a significant surface rupture as indicated by both historical 248 (Ambraseys and Jackson 1998) and palaeoseismological studies (Çetin et al., 2003). During the 249 event, the rupture length reached $45 \mathrm{~km}$ and the block at the southeast of Lake Hazar was 250 uplifted by 1 to $2 \mathrm{~m}$ along the rupture zone (Ambraseys, 1989). Herece (2008) measured a $2.6 \mathrm{~m}$ 251 left-lateral offset created by the 1874 earthquake (Table 3). Recent the fieldwork of Duman and 252 Emre (2013) raised the average displacement of the 1874 earthquake to $3.5+0.5 \mathrm{~m}$ (Table 3).

A year later in 1875, a Ms 6.7 earthquake occurred on the northwestern part of the 254 Pütürge Segment (Ambraseys, 1989; Ambraseys and Jackson 1998; Herece, 2008). On the contrary, Duman and Emre (2013) suggested that this earthquake occurred on the southwestern part of the Palu segment which they called Lake Hazar releasing bend. In our opinion, this 257 proposition cannot be correct because their Lake Hazar releasing bend is only a $10 \mathrm{~km}$ long fault 258 zone (Duman and Emre, 2013), hence, incapable to create a Ms 6.7 earthquake. It has been 259 known that the 1875 earthquake caused a $20 \mathrm{~km}$ long surface faulting (Ambraseys and Jackson, 260 1998). We think that this value is a better assumption because close-sized (Mw 6.8) earthquakes 261 occurred on the EAFZ in the instrumental period formed at least $35 \mathrm{~km}$ long surface faulting 262 (Table 3). No offset was detected in the field related to the 1875 earthquake (cf., Herece, 2008; 263 Duman and Emre, 2013). 
267 According to Duman and Emre (2013), this event caused the formation of 86-km-long surface 268 faulting. The damage zone covered a $220 \mathrm{~km}$ long, and $120 \mathrm{~km}$ wide area (Ambraseys, 1989).

269 When the highly destructive nature of this event (Ambraseys, 1989) evaluated together with the 270 86-km-long surface faulting (Duman and Emre, 2013) it can be speculated that the magnitude of 271 the 1893 earthquake could be even higher than the Ms 7.1.

In 1905, a Ms 6.8 earthquake (Ambraseys 1989; Ambraseys \& Jackson 1998) generated

273 along the Pütürge Segment (Fig. 5) (Duman and Emre, 2013). As a result of this earthquake,

274 heavy damage with loss of life occurred in the mountain villages between Pütürge and Çelikhan

275 and the shock caused widespread liquefaction of the Euphrates river deposits (Ambraseys 1989).

276 It is reported that the earth was split into many places, the road is cut, presumably by landslides

277 (Ambraseys 1989) with no co-seismic surface slip (Table 3). These observations, including lack

278 of co-seismic surface slip, is very similar to our observations on the 2020 earthquake. According

279 to Duman and Emre (2013), the 1905 earthquake may have occurred on the 15-km-long

280 Yarpuzlu bend that makes the southwestern part of the Pütürge Segment. On the contrary,

281 Nalbant et al. (2002) suggested that 38-km-long surface faulting may have been formed by the

2821905 earthquake. Considering the size of the damage zone (Ambraseys 1989), we prefer Nalbant 283 et al. (2002)'s suggestion on the length of the co-seismic surface faulting (Table 3).

284 Except the 2020 earthquake, only one major earthquake occurred in the $21^{\text {st }}$ century 285 which is the Mw 6.8, 1971 Bingöl earthquake (McKenzie, 1972; Taymaz et al., 1991). This 286 earthquake created a discontinuous 35-km-long surface rupture along the Göynük Valley of 287 Bingöl (Arpat and Şaroğlu, 1972; Seymen and Aydın, 1972). The earthquake caused heavy 288 damage with loss of life in the Bingöl city center and the neighboring villages (Arpat and 289 Şaroğlu, 1972; Seymen and Aydın, 1972). During the 1971 earthquake, the whole length of the 290 35-km-long Ilica Segment was ruptured (Fig. 5) (Duman and Emre, 2013). A maximum left291 lateral co-seismic offset of $25 \mathrm{~cm}$ reported after the 1971 earthquake (Table 3) (Seymen and 292 Aydın, 1972) which is significantly small compared with the co-seismic offset values reported 293 after the $\mathrm{Ms} \geq 7.1$ earthquakes of the $19^{\text {th }}$ century (Table 3). Along the tension gashes oriented 294 nearly perpendicular to the main fault, 5 to $10 \mathrm{~cm}$ vertical offset was also formed during the 295 Bingöl earthquake (Arpat and Şaroğlu, 1972).

\section{6.2. THE SEISMIC GAPS ALONG THE EAST ANATOLIAN FAULT}


As it is shown in Figure 5, two segments with a total length of $108 \mathrm{~km}$ seem to be carrying a high risk of major earthquakes; the Gökdere and the Pazarcık Segments (Nalbant et al., 2002; Duman and Emre, 2013). Additionally, the approximately 20-km-long northeastern part of the Palu Segment which is in connection with the Gökdere Segment also seemed to be a seismic gap (Fig. 5). Some InSAR studies suggest that the 100-km-long Palu Segment (actually it is 77-km-long; see Duman and Emre, 2013) is exhibiting a seismic creep at the surface (e.g., Özarpac1 et al., 2017). However, the rupture length analyses on the 1874 and 1875 earthquakes (Fig. 5; Table 3) do not reconcile with fault creep documented by InSAR.

According to the Duman and Emre (2013), the Gökdere Segment (or their Gökdere Restraining Bend) is a 25-km wide, $45 \mathrm{~km}$-long fault jog. On the contrary, Herece (2008) defines a 15-km wide, $30 \mathrm{~km}$-long uplift zone in the north and another $50 \mathrm{~km}$ long narrow fault zone in the south of the Bingöl pull-apart basin (the Genç Segment of the Arpat and Şaroğlu, 1972) in the region of the Duman and Emre (2013)'s Gökdere Segment. Our recent ongoing mapping supports the existence of two major faults as Herece (2008) reports. It is clear that some stress transfer likely to have taken place to the Gökdere (Duman and Emre, 2013) and/or the Genç

312 Segments generated by the 1971 (M 6.8) Bingöl earthquake. Hence, a 45 to 50-km-long

313 earthquake rupture with a possible magnitude between Mw 6.7 and 7.0 (see Table 4 for rupture314 magnitude relationship) is likely to happen along the southern or northern border of Bingöl pull315 apart basin in the future. Because of lack of aggrement on fault structure and the geographic 316 position of the Bingöl City center, here we call this seismic gap as the Bingöl Seismic Gap (Fig. 317 5B).

The Pazarcık Segment is probably the most dangerous seismic gap of the EAFZ (Fig. 5) (Nalbant et al., 2002; Karabacak et al. 2011; Duman and Emre, 2013). Here we call this seismic gap as the Kahramanmaraş Seismic Gap (Fig. 5B) because Kahramanmaraş would be the most affected city by a future earthquake. Based on palaeoseismological studies a recurrence interval 322 of 350-400 years and a slip rate of $9.18 \pm 054 \mathrm{~mm} \mathrm{yr}^{-1}$ were suggested for the Pazarckk Segment 323 (Karabacak et al. 2011; Duman and Emre, 2013). The latest known earthquake occurred on the 324 Pazarcik Segment is the Ms 7.4, 1513 earthquake (Ambraseys, 1989). Coulomb stress modeling 325 shows that the 1822 event increased stress over the Pazarckk Segment by as much as 8 bar which 326 caused a strain accumulation of c. $3.5 \mathrm{~m}$ (Nalbant et al., 2002). By using the time elapsed since 327 the last large earthquake (491 years) and the amount of strain accumulation (3.5 $\mathrm{m}$ ) a maximum 
magnitude of Mw 7.3 is suggested for the future earthquake that will probably occur on the

329 Pazarcik Fault (Nalbant et al., 2002).

7. CONCLUSIONS

January 24, 2020, Sivrice Mw 6.8 earthquake created a 54-km-long surface rupture along the Pütürge segment of the East Anatolian Fault. No co-seismic surface slip has been formed during the earthquake. The deformation observed as intense ground fissures, rock falls,

334 landslides, liquefaction of various lengths. Evaluation of the data collected after the 2020 earthquake with the data of the earlier events suggest that (1) the large co-seismic left-lateral surface slip (between 2.0 and 4.5 meters) only occurs when the earthquake magnitudes reach to Mw 7.0 along the EAFZ, and (2) 130 km long part of the EAFZ remains as seismic gaps (the $20 \mathrm{~km}$-long part of the Palu Segment, the Pazarcık and the Gökdere Segments) at least since 1822.

\section{ACKNOWLEDGMENTS}

341 We express gratitude and appreciation to the Bingöl Central Municipality and Elit Eğitim

342 Schools (Malatya) for providing support during fieldwork. The earthquake location and focal

343 mechanism solutions were provided by the Ministry of Interior Disaster and Emergency

344 Management Presidency of Turkey (AFAD).

\section{REFERENCES}

346
Aksoy E, İnceöz M, Koçyiğit A (2007). Lake Hazar Basin: a negative flower structure on the East Anatolian Fault System (EAFS), SE Turkey. Turkish J Earth Sci 16: 319-338.

Aktuğ B, Özener H, Dogru A, Sabuncu A, Turgut B, Halıcıoğlu K, Yilmaz O, Havazlı E (2016). Slip rates and seismic potential on the East Anatolian Fault System using an improved GPS velocity field. J Geodynamics 94-95: 1-12.

Allen CR (1969). Active Faulting in Northern Turkey. Pasadena, CA, USA: Division of Geological Sciences, California Institute of Technology.

Altınlı E (1963). 1/500.000 Ölçekli Türkiye Jeoloji Haritası Erzurum Paftası İzahnamesi, Maden Tetkik ve Arama Enstitüsü Yayınları, No: 131, Ankara (in Turkish).

Ambraseys NN (1989). Temporary seismic quiescence: SE Turkey. Geophys J Int 96: 311-331.

Ambraseys NN, Jackson JA (1998). Faulting associated with historical and recent earthquakes in the Eastern Mediterranean region. Geophys J Int 133: 390-406.

Arpat E, Şaroğlu F (1972). The East Anatolian Fault System: thoughts on its development. Bulletin of the Mineral Research and Exploration (MTA) 78: 33-39. 
Arpat E, Şaroğlu F (1975). Recent tectonic activities in Turkey. Bulletin of the Geological Society of Turkey 18: 91-101 (in Turkish with English abstract).

Barka A, Kadinsky-Cade K (1988). Strike-slip fault geometry in Turkey and its influence on earthquake activity. Tectonics 7: 663-684.

Bulut F, Bohnhoff M, Eken T, Janssen C, K1lıç T, Dresen G (2012). The East Anatolian Fault Zone: Seismotectonic setting and spatiotemporal characteristics of seismicity based on precise earthquake locations. J Geophys Res 117: 1-16.

Çetin H, Güneyli H, Mayer L (2003). Paleosismology of the Palu-Lake Hazar segment of the East Anatolian Fault Zone, Turkey. Tectonophysics 374: 163-197.

Dewey JF, Hempton MR, Kidd WSF, Şaroglu F, Şengör AMC (1986). Shortening of continental lithosphere: the neotectonics of Eastern Anatolia - a young collision zone. Geol Soc London Spec Publ 19(1): 1-36.

Duman TY, Emre Ö (2013). The East Anatolian Fault: geometry segmentation and jog characteristics. Geol Soc London Spec Publ 372: 495-529.

Ergintav S, Reilinger RE, Çakmak R, Floyd M, Çakır Z, Doğan U, King RW, McClusky S, Özener H (2014). Istanbul's earthquake hot spots: Geodetic constraints on strain accumulation along faults in the Marmara seismic gap. Geophys Res Lett 41: doi:10.1002/2014GL060985.

Guidoboni E, Comastri A, Triana G (1994). Catalogue of ancient earthquakes in the Mediterranean area up to the $10^{\text {th }}$ Century. Istituto Nazionale di Geofisica, Rome.

Havskov J, Ottemoller L (1999). SeisAn Earthquake Analysis Software. Seis Res Lett 70(5): 532-534.

Hempton MR (1985). Structure and deformation history of Bitlis suture near Lake Hazar, southeastern Turkey. Bull Geo Soc Am 96: 233-243.

Hempton MR (1987). Constraints on Arabian plate motion and extensional history of the Red Sea. Tectonics 6: 687-705.

Hempton MR, Dewey JF, Şaroğlu F (1981). The East Anatolian transform fault: along strike variations in geometry and behavior. EOS T Am Geophys Un 62: 393.

Herece E (2008). Atlas of East Anatolian Fault. General Directorate of Mineral Research and Exploration (MTA) Special Publications Serial Number 13, Ankara, Turkey.

Herece E, Akay E (1992). Karlıova-Çelikhan arasında Doğu Anadolu Fayı. In: 9th Petroleum Congress of Turkey Proceedings Abstract Book 1: 361-372.

Jackson J, McKenzie DP (1984). Active tectonics of the Alpine-Himalayan belt between western Turkey and Pakistan. Geophys J Roy Astr S 77: 185-264.

Kalafat D, Güneş Y, Kekovalı K, Kara M, Deniz P, Yılmazer M (2011). A revised and extented earthquake cataloque for Turkey since 1900 ( $\mathrm{M} \geq 4.0$ ) (in Turkish). Boğaziçi University, Kandilli Observatory and Earthquake Research Institute, Istanbul, 1049, 640 pp.

Karabacak V, Önder Y, Altunel E, Yalçıner CC, Akyüz HS, Kıyak NG (2011). Doğu Anadolu Fay Zonunun güney batı uzanımının paleosismolojisi ve ilk kayma hızı. Proceeding of the Aktif Tektonik Araştırma Grubu Onbeşinci Çalıştayı (ATAG-15), Adana, 17. 
Karig DE, Kozlu H (1990). Late Paleogene-Neogene evolution of the triple junction region near Maraş, south-central Turkey. J of the Geol Soc London 147: 1023-1034.

Khalifa A, Çakır Z, Owen LA, Kaya Ş (2018). Morphotectonic analysis of the East Anatolian Fault, Turkey. Turkish J Earth Sci 27(2): 110-126.

Kiratzi A (1993). A study on the active crustal deformation of the North and East Anatolian Fault Zones. Tectonophysics 225: 191-203.

Kondorskaya NV, Ulomov VI (1999). Special catalogue of earthquakes of the Northern Eurasia (SECNE). http://www.seismo.ethz.ch/static/gshap/neurasia/nordasiacat.txt

Mahmoud Y, Masson F, Meghraoui M, Cakir Z, Alchalbi A, Yavasoglu H, Yönlü Ö, Daoud M, Ergintav S, Inan S (2013). Kinematic study at the junction of the East Anatolian fault and the Dead Sea fault from GPS measurements. J Geodyn 67: 30-39.

McKenzie DP (1972). Active tectonics of the Mediterranean region. Geophys J Int 30: 109-185.

McKenzie DP (1976). The East Anatolian fault: a major structure in eastern Turkey. Earth Planet Sc Lett 29: 189-193.

McKenzie DP (1978). Active tectonics of the Alpine- Himalayan belt: The Aegean Sea and surrounding regions (tectonic of Aegean region). Geophys J Roy Astr S 55: 217-254.

Muehlberger WR, Gordon MB (1987). Observations on the complexity of the East Anatolian Fault, Turkey. J Struct Geol 9: 899-903.

Nalbant SS, McCloskey J, Steacy S, Barka AA (2002). Stress accumulation and increased seismic risk in eastern Turkey. Earth Planet Sc Lett 195(3-4): 291-298.

Özarpacı S, Ergintav S, Çakır Z, Doğan U, Şentürk S, Karabulut H, Şaroğlu F, Dikmen Ü, Bilham R, Özdemir A, Julaiti W, Özener H (2017). Aseismic slip and surface creep on the Hazar-Palu Section of the East Anatolian Fault, Turkey. In: AGU Fall Meeting Abstracts T21A-0540.

Ozer C, Ozyazıcıoğlu M, Gök E, Polat O (2019). Imaging the Crustal Structure throughout the East Anatolian Fault Zone, Turkey, by Local Earthquake Tomography. Pure and Applied Geophysics 176(6): 2235-2261.

Perinçek D, Çemen İ (1990). The structural relationship between the East Anatolian and Dead Sea fault zones in southeastern Turkey. Tectonophysics 172: 331-340.

Pınar, N., Lahn. E. (1952). Türkiye Depremleri İzahlı Kataloğu. Bayındırlık Bakanlı̆̆ı, Yapı \& İmar İşleri Reisliği Yayınları, Ankara.

Pousse-Beltran L, Nissen E, Bergman EA, Cambaz MD, Gaudreau É, Karasözen E, Tan F (2020). The $2020 \mathrm{Mw} 6.8$ Elazığ (Turkey) earthquake reveals rupture behavior of the East Anatolian Fault. Geop Res Lett e2020GL088136.

Reilinger R, McClusky S (2011). Nubia-Arabia-Eurasia plate motions and the dynamics of Mediterranean and Middle East tectonics. Geophys J Int 186(3): 971-979.

Reilinger R, McClusky S, Vernant P, Lawrence S, Ergintav S, Cakmak R, Ozener H, Kadirov F, Guliev I, Stepanyan R et al. (2006). GPS constraints on continental deformation in the Africa-Arabia-Eurasia continental collision zone and implications for dynamics of plate interactions. J Geophys Res 111: 1-26. 
Şaroğlu F (1985). Dogu Anadolu'nun Neotektonik Dönemde Jeolojik ve Yapısal Evrimi (Ph.D. thesis). İstanbul Üniv., Fen Bilim. Enst., Istanbul. 240 pp.+7 foldouts.

Şaroğlu F, Emre Ö, Kuşçu I (1992). The East Anatolian fault zone of Turkey. Annales Tectonicae 6: 99-125.

Shebalin NV, Tatevossian RE (1997). Catalogue of large historical earthquakes of the Caucasus. NATO ASI Series Partnership Sub-series Environment 2-28: 201-232, Kluwer Academic Publishers, Dordrecht, The Netherlands.

Seymen İ, Aydın A (1972). The Bingöl earthquake fault and its relation to the North Anatolian Fault Zone. Bulletin of the General Directorate of Mineral Research and Exploration 79: $1-8$.

Seyrek A, Demir T, Pringle MS, Yurtmen S, Westaway RWC, Beck A, Rowbotham G (2007). Kinematics of the Amanos Segment, southern Turkey, from Ar/Ar dating of ofset Pleistocene basalt flows: transpression between the African and Arabian plates. Geol Soc London Spec Publ 290: 255-284.

Şengör AMC (1979). The North Anatolian transform fault: Its age, offset and tectonic significance. J Geol Soc London 136: 269-282.

Şengör AMC, Görür N, Şaroğlu F (1985). Strike slip faulting and related basin formation in zones of tectonic escape: Turkey as a case study. In: Biddle KT, Christie-Blick N, editors. Strike-Slip Deformation, Basin Formation and Sedimentation. Tulsa, OK, USA: Society of Economic Paleontologists and Mineralogists, pp. 227-264.

Tan O, Tapırdamaz MC, Yörük A (2008). The earthquake catalogues for Turkey. Turkish J Earth Sci 17: 405-418.

Taymaz T, Eyidoğan H, Jackson J (1991). Source parameters of large earthquakes in the East Anatolian Fault Zone (Turkey). Geophys J Int 106: 537-50.

Westaway R (1994). Present-day kinematics of the Middle East and eastern Mediterranean. J Geophys Res 99: 12071-12090.

Westaway R (2003). Kinematics of the Middle East and Eastern Mediterranean updated. Turkish J Earth Sci 12: 5-46.

Westaway R, Arger J (1996). The Gölbaşı basin, southeastern Turkey: a complex discontinuity in a major strike-slip fault zone. Geol Soc London Spec Publ 153: 729-743.

Yönlü Ö, Altunel E, Karabacak V, Akyüz HS (2013). Evolution of the Gölbaşı basin and its implications for the long-term offset on the East Anatolian Fault Zone, Turkey. J Geodyn 65: 272-281.

Yönlü Ö, Altunel E, Karabacak V (2017). Geological and geomorphological evidence for the southwestern extension of the East Anatolian Fault Zone, Turkey. Earth Planet Sc Lett 469: 1-14.

Yürür MT, Chorowicz J (1998). Recent volcanism, tectonics and plate kinematics near the junction of the African, Arabian and Anatolian plates in the Eastern Mediterranean. J Volcanol Geotherm Res 85: 1-15.

\section{FIGURE CAPTIONS}


Figure 1. A: Tectonic map of the eastern Mediterranean and the Middle East. Arrows and numbers indicate the global positioning system (GPS)-derived velocities ( $\mathrm{mm} \mathrm{yr}^{-1}$ ) with respect to Eurasia (Reilinger and McClusky, 2011; Ergintav et al., 2014). EAFZ: East Anatolian Fault Zone; DSFZ: Dead Sea Fault Zone; BZATZ: Bitlis Zagros Active Thrust Zone; NAFZ: North Anatolian Fault Zone; RAE: Region of Aegean Extension. B: The map of the EAFZ between Karlıova (Bingöl) and Kahramanmaraş (Km) and the map of DSFZ between Kahramanmaraş and Antakya. The fault map is redrawn from Duman and Emre (2013). Please note that the DSFZ has been mapped as the Amanos Segment of the EAFZ in Duman and Emre (2013). The colored faults are the fault fragments that were ruptured during $\mathrm{Mw}>6.5$ earthquakes in the last 200 years. The colored numbers refer to years of the earthquakes that ruptured each fault. The earthquake data have been compiled from Ambraseys (1989), Guidoboni et al. (1994), Shebalin and Tatevossian (1997), Ambraseys and Jackson (1998), Kondorskaya and Ulomov (1999), Tan et al. (2008) and our study. For the review of the earthquake data see also Duman and Emre (2013). DSFZ: Dead Sea Fault Zone; Siv.: Sivrice.

494 Figure 2. A: The map of the Pütürge Segment and the eastern part of the Palu Segment of the EAFZ, and the position-focal mechanism solutions of the $M \geq 4.0$ events that occurred before the 2020 earthquake (see also Table 1) shown over the Digital Elevation Model (DEM). The faults are redrawn from Duman and Emre, 2013. B: The position and the focal mechanism solutions of the 2020 earthquake (in red) and the $\mathrm{Mw} \geq 4.0$ aftershocks (see also Table 2) shown over the DEM. C: The depth and the location of the $\mathrm{Mw} \geq 3.0$ aftershocks. The solutions of the $\mathrm{Mw} \geq 4.0$ aftershocks are also shown (redrawn from AFAD database).

Figure 3. A: The active fault map of the Pütürge Segment between Ormaniçi and Tosunlu

502 Villages and the position of the observed deformations (numbered). Black faults are from Duman 503 and Emre (2013), the red faults are drawn during this study. B: The pressure ridge with extensive ground fissures formed during the 2020 earthquake, south of the Mollahan Stream. C: Deepreaching ground fissures at the north of the Mollahan Stream. D: The liquefaction area at the east of Ormaniçi on 25 January 2020 (upper) and on 4 May 2020 (lower). E: An extensional, discontinuous ground fissure in Tosunlu Village. The numbers in figures are the location numbers shown in Figure 3A. See text and also Table 3 for the explanation. 
Figure 4. A: The active fault map of the Pütürge Segment between Doğanyol (Malatya) and Sivrice (Elazığ) and the position of the observed deformations (numbered). Faults are from

511 Duman and Emre (2013). B: The heavily damaged mosque in Sivrice. C: The photograph of the 512 load-bearing columns of the Sivrice Mosque. Please pay attention to the lack of lateral

513 reinforcement binders. D: A gravitational cracks with up to $40-50 \mathrm{~cm}$ downward movement. E:

514 A surface crack that caused severe damage to telephone poles. F: The co-seismically formed 515 pressure ridge south of the Çevrimtaş Village. The water body is the Karakaya Dam Lake that 516 filled the Euphrates River Valley. G: The cracks formed over the pressure ridge with an average $517 \quad$ N80E direction.

518 Figure 5. A: The map of the EAFZ between Karlıova (Bingöl) and Kahramanmaraş (Km) and 519 the map of DSFZ between Kahramanmaraş and Antakya. Fault map and segment names (accept 520 DSFZ) are from Duman and Emre (2013). For the location of this figure see Fig. 1A. B: The 521 rupture lengths vs rupture year of the major earthquakes $(6.3 \leq \mathrm{Ms} \leq 7.5)$ occurred along the EAFZ 522 and the northern part of the DSFZ since the 1822. Those that caused formation of co-seismic 523 surface slip are indicated with continuous lines. Those that were not caused formation of co524 seismic surface slip are indicated with dashed lines. The earthquakes have been compiled from 525 Ambraseys (1989), Guidoboni et al. (1994), Shebalin and Tatevossian (1997), Ambraseys and 526 Jackson (1998), Kondorskaya and Ulomov (1999), Tan et al. (2008) and our study. For the 527 review of the earthquake data see also Duman and Emre (2013).

\section{TABLE CAPTIONS}

529 Table 1. Parameters for fault plane solutions of the $\mathrm{M} \geq 4.0$ foreshocks of the 2020 earthquake 530 occured between 2007 and 2019 (from AFAD database) depicted in Figure 2A.

531 Table 2. Parameters for fault plane solutions of the 2020 earthquake and its $M w \geq 4.0$ aftershocks 532 (from AFAD database) depicted in Figure 2B-2C.

533 Table 3. Field data of the 24 January $2020 \mathrm{Mw} 6.8$ Doğanyol-Sivrice earthquake.

534 Table 4. Earthquakes (Ms $\geq 6.7)$ on the EAFZ since 1866 with the co-seismic surface slip values 535 reported for each earthquake. Dates, magnitudes, epicenters and observed fault lengths of the are 536 from, Arpat and Şaroğlu (1972, McKenzie (1972), Seymen and Aydın (1972), Ambraseys 537 (1989), Ambraseys and Jackson (1998), and Nalbant et al. (2002). Date, magnitude, the epicenter 
538 of the 2020 earthquake is from AFAD and ruptured fault length is measured during our study.

539 Segment names are from Duman and Emre (2013). 


\section{Table 1}

\begin{tabular}{|c|c|c|c|c|c|c|c|c|}
\hline $\begin{array}{l}\text { Event no } \\
\text { (in Fig. 2A) }\end{array}$ & \multicolumn{2}{|c|}{$\begin{array}{l}\text {---Date / Hour (GMT)---- } \\
\text { (dd/mm/yy) / (hh:mm:ss) }\end{array}$} & $\begin{array}{l}\text { Latitude } \\
\qquad\left(\mathrm{N}^{\circ}\right)\end{array}$ & $\begin{array}{l}\text { Longitude } \\
\qquad\left(\mathrm{E}^{\circ}\right)\end{array}$ & Strike & Dip & Rake & $\begin{array}{l}\text { Magnitude } \\
\text { (Type) }\end{array}$ \\
\hline 1 & $11 / 02 / 2007$ & $06: 23: 48$ & 38.4742 & 39.0655 & 225.0 & 81.0 & -11.0 & $4.2(\mathrm{Ml})$ \\
\hline 2 & $21 / 02 / 2007$ & $11: 05: 26$ & 38.3827 & 39.3082 & 262.0 & 60.0 & 6.0 & $5.4(\mathrm{Ml})$ \\
\hline 3 & 28/02/2007 & 20:08:10 & 38.3843 & 39.1932 & 247.0 & 78.0 & 8.0 & $4.2(\mathrm{Ml})$ \\
\hline 4 & 28/02/2007 & $23: 27: 46$ & 38.3487 & 39.2607 & 40.0 & 75.0 & -12.0 & $4.3(\mathrm{Ml})$ \\
\hline 5 & $14 / 04 / 2007$ & $04: 30: 37$ & 38.3528 & 39.2848 & 244.0 & 57.0 & 8.0 & $4.5(\mathrm{Ml})$ \\
\hline 6 & $22 / 03 / 2009$ & & & & & 61.0 & 35.0 & $4.0(\mathrm{Ml})$ \\
\hline 7 & 07/07/2009 & $15: 57: 02$ & 38.2547 & 38.7407 & 200.0 & 38.0 & -41.0 & $5.0(\mathrm{Ml})$ \\
\hline 8 & 05/10/2009 & 01:58:08 & 38.3683 & 39.2918 & 247.0 & 78.0 & -17.0 & $4.0(\mathrm{Ml})$ \\
\hline 9 & 23/06/2011 & $07: 34: 43$ & 38.5562 & 39.6307 & 259.0 & 83.0 & 15.0 & $5.3(\mathrm{Ml})$ \\
\hline 10 & $23 / 06 / 2011$ & $12: 00: 06$ & 38.5867 & 39.6008 & 141.0 & 83.0 & 134.0 & $4.0(\mathrm{Ml})$ \\
\hline 11 & 04/08/2011 & 03:13:08 & 38.5952 & 39.6348 & 252.0 & 90.0 & 2.0 & $4.4(\mathrm{Ml})$ \\
\hline 12 & 10/10/2011 & $07: 14: 31$ & 38.4543 & 39.2525 & 356.0 & 58.0 & -128.0 & $4.0(\mathrm{Ml})$ \\
\hline 13 & 28/08/2013 & 06:26:08 & 38.3793 & 38.9065 & 257.0 & 78.0 & 5.0 & $4.2(\mathrm{Ml})$ \\
\hline 14 & 19/01/2018 & & & & 230.0 & 81.0 & 3.0 & $4.1(\mathrm{Mw})$ \\
\hline 15 & 04/04/2019 & $17: 31: 07$ & 38.3865 & 39.1205 & 345.0 & 84.0 & 173.0 & $5.2(\mathrm{Mw})$ \\
\hline 16 & 27/12/2019 & $07: 02: 25$ & 38.3898 & 39.0158 & 346.0 & 86.0 & -139.0 & $4.9(\mathrm{Mw})$ \\
\hline
\end{tabular}


Table 2

Event no ---Date / Hour (GMT)---- Latitude Longitude Depth Strike Dip Rake Magnitude (in Fig. 2B) (dd/mm/yy) / (hh:mm:ss)

$\left(\mathrm{N}^{\circ}\right) \quad\left(\mathrm{E}^{\circ}\right) \quad(\mathrm{km}) \quad(\mathrm{Mw})$

\begin{tabular}{rrrrrrrrrr}
\hline 1 & $24 / 01 / 2020$ & $17: 55: 11$ & 38.3593 & 39.0630 & 8.06 & 248.0 & 76.0 & 1.0 & 6.8 \\
2 & $24 / 01 / 2020$ & $18: 08: 05$ & 38.4140 & 39.2006 & 7.03 & 257.0 & 78.0 & 5.0 & 4.5 \\
3 & $24 / 01 / 2020$ & $18: 17: 57$ & 38.3891 & 38.9261 & 14.62 & 230.0 & 81.0 & 3.0 & 4.1 \\
4 & $24 / 01 / 2020$ & $18: 32: 35$ & 38.3698 & 39.0316 & 13.01 & 240.0 & 79.0 & 5.0 & 4.6 \\
5 & $24 / 01 / 2020$ & $18: 36: 22$ & 38.2676 & 38.7096 & 6.96 & 249.0 & 57.0 & 3.0 & 4.3 \\
6 & $24 / 01 / 2020$ & $19: 03: 07$ & 38.2675 & 38.7088 & 11.22 & 340.0 & 70.0 & -162.0 & 4.6 \\
7 & $24 / 01 / 2020$ & $19: 49: 38$ & 38.4186 & 39.1520 & 14.84 & 246.0 & 84.0 & 4.0 & 4.5 \\
8 & $24 / 01 / 2020$ & $20: 42: 10$ & 38.3681 & 39.0995 & 7.25 & 259.0 & 83.0 & 18.0 & 4.1 \\
9 & $24 / 01 / 2020$ & $20: 45: 03$ & 38.4233 & 39.1463 & 13.50 & 259.0 & 83.0 & 15.0 & 4.3 \\
10 & $25 / 01 / 2020$ & $00: 48: 51$ & 38.4883 & 39.2030 & 7.57 & 271.0 & 68.0 & 2.0 & 4.3 \\
11 & $25 / 01 / 2020$ & $06: 07: 33$ & 38.3848 & 39.0368 & 16.46 & 336.0 & 80.0 & -158.0 & 4.2 \\
12 & $25 / 01 / 2020$ & $08: 40: 03$ & 38.4790 & 39.2895 & 13.65 & 246.0 & 67.0 & -9.0 & 4.4 \\
13 & $25 / 01 / 2020$ & $10: 14: 56$ & 38.2760 & 38.7530 & 11.01 & 245.0 & 81.0 & -21.0 & 4.5 \\
14 & $25 / 01 / 2020$ & $16: 30: 07$ & 38.3740 & 39.1310 & 16.40 & 244.0 & 58.0 & -7.0 & 5.1 \\
15 & $25 / 01 / 2020$ & $16: 44: 01$ & 38.3926 & 39.1235 & 11.86 & 247.0 & 74.0 & -13.0 & 4.4 \\
16 & $25 / 01 / 2020$ & $16: 44: 23$ & 38.4101 & 39.1071 & 12.25 & 248.0 & 87.0 & -4.0 & 4.3 \\
17 & $25 / 01 / 2020$ & $16: 45: 06$ & 38.3833 & 39.1268 & 7.00 & 246.0 & 84.0 & 4.0 & 4.1 \\
18 & $25 / 01 / 2020$ & $16: 46: 58$ & 38.3896 & 39.0806 & 12.06 & 246.0 & 67.0 & -9.0 & 4.3 \\
19 & $27 / 01 / 2020$ & $16: 12: 00$ & 38.3950 & 39.1333 & 11.94 & 165.0 & 84.0 & -172.0 & 4.2 \\
20 & $31 / 01 / 2020$ & $23: 32: 49$ & 38.4916 & 39.3286 & 15.56 & 212.0 & 85.0 & -14.0 & 4.5 \\
21 & $01 / 02 / 2020$ & $00: 03: 49$ & 38.4511 & 39.2505 & 19.92 & 53.0 & 83.0 & -10.0 & 4.2 \\
22 & $03 / 02 / 2020$ & $22: 19: 40$ & 38.3986 & 39.1543 & 7.18 & 240.0 & 85.0 & 22.0 & 4.5 \\
23 & $17 / 02 / 2020$ & $11: 42: 13$ & 38.3960 & 39.1150 & 11.64 & 65.0 & 84.0 & -1.0 & 4.2 \\
24 & $25 / 02 / 2020$ & $23: 03: 36$ & 38.3291 & 38.7696 & 14.29 & 245.0 & 43.0 & -15.0 & 4.9 \\
25 & $27 / 02 / 2020$ & $02: 08: 45$ & 38.2525 & 38.6566 & 7.00 & 346.0 & 59.0 & -136.0 & 4.1 \\
26 & $29 / 02 / 2020$ & $12: 29: 46$ & 38.4421 & 39.2356 & 8.15 & 233.0 & 87.0 & 8.0 & 4.6
\end{tabular}


Table 3

\begin{tabular}{|c|c|c|c|c|}
\hline $\begin{array}{l}\text { Location no in } \\
\text { Figs. 3A or } 4 \mathrm{~A}\end{array}$ & $\begin{array}{l}\text { Latitude } \\
\left(\mathrm{N}^{\circ}\right)\end{array}$ & $\begin{array}{l}\text { Longitude } \\
\left(\mathrm{E}^{\circ}\right)\end{array}$ & $\begin{array}{l}\text { Strike of } \\
\text { structure }\end{array}$ & Short explanation \\
\hline 1 & 38.769 & 38.198 & N55E & Pressure ridge with ground fissures \\
\hline 2 & 38.773 & 38.211 & N75E & Deep reaching ground fissures \\
\hline 3 & 38.227 & 38.814 & N80E & Ground fissures \\
\hline 4 & 38.822 & 38.225 & na & Liquefaction \\
\hline 5 & 38.280 & 38.918 & N70E & Gravitational cracks \\
\hline 6 & 39.069 & 38.345 & N85E & Pressure ridge parallel to the local main fault direction \\
\hline 7 & 39.104 & 38.363 & $\mathrm{~N} 75 \mathrm{E}$ & Gravitational cracks \\
\hline 8 & 39.109 & 38.363 & N60E & Gravitational cracks \\
\hline 9 & 39.169 & 38.385 & na & Towards S co-seismic landslides were observed \\
\hline 10 & 39.182 & 38.384 & $\mathrm{~N} 40 \mathrm{E}$ & Cracks along the road \\
\hline 11 & 39.183 & 38.385 & na & Trees up to $50 \mathrm{~cm}$ diameter have been overturned \\
\hline 12 & 38.385 & 39.183 & N50E & $\begin{array}{l}\text { The telephone poles and the trees cut by the fault } \\
\text { cracks were collapsed }\end{array}$ \\
\hline 13 & 39.186 & 38.387 & N70E & Gravitational cracks; $40-50 \mathrm{~cm}$ downward movement \\
\hline 14 & 39.184 & 38.389 & na & Liquefaction \\
\hline 15 & 39.191 & 38.390 & na & Gravitational cracks \\
\hline 16 & 38.423 & 39.281 & N70E & Gravitational cracks \\
\hline 17 & 38.427 & 39.266 & N65E & Gravitational cracks \\
\hline 18 & 38.412 & 39.205 & N60E & Gravitational cracks \\
\hline 19 & 38.448 & 39.309 & na & $\begin{array}{l}\text { Heavy damage of the Sivrice Mosque } \\
\text { N-S directed cracks on the road } \\
\text { N-S directed windows are all broken }\end{array}$ \\
\hline
\end{tabular}




\section{Table 4}

\begin{tabular}{|c|c|c|c|c|c|c|}
\hline $\begin{array}{c}\text { Date } \\
(\mathrm{dd} / \mathrm{mm} / \mathrm{yy})\end{array}$ & $\begin{array}{l}\text { Magnitude } \\
\quad(\mathrm{Ms})\end{array}$ & $\begin{array}{l}\text { Epicenter- } \\
\operatorname{Lat}\left(\left(^{\circ}\right)-\operatorname{Lon}\left({ }^{\circ}\right)\right.\end{array}$ & $\begin{array}{l}\text { Ruptured } \\
\text { Segment }\end{array}$ & $\begin{array}{l}\text { Ruptured } \\
\text { Length }(\mathrm{km})\end{array}$ & $\begin{array}{l}\text { Co-seismic } \\
\text { surface slip (m) }\end{array}$ & $\begin{array}{l}\text { Reference of the } \\
\text { co-seismic surface slip }\end{array}$ \\
\hline $12 / 05 / 1866$ & 7.2 & $39.2 \mathrm{~N}-41.0 \mathrm{E}$ & Karlıova & 45 & $3.5 \pm 0.1$ & Herece (2008) \\
\hline 03/05/1874 & 7.1 & $38.5 \mathrm{~N}-39.5 \mathrm{E}$ & Palu & 45 & $\begin{array}{l}2.6 \\
3.5 \pm 0.5\end{array}$ & $\begin{array}{l}\text { Herece (2008) } \\
\text { Duman and Emre (2013) }\end{array}$ \\
\hline 27/03/1875 & 6.7 & $38.5 \mathrm{~N}-39.5 \mathrm{E}$ & Pütürge & 20 & not observed & \\
\hline $02 / 03 / 1893$ & 7.1 & $38.0 \mathrm{~N}-38.3 \mathrm{E}$ & Erkenek & 86 & 4.5 & Herece (2008) \\
\hline 04/12/1905 & 6.8 & $38.1 \mathrm{~N}-38.6 \mathrm{E}$ & Pütürge & 38 & not observed & \\
\hline 22/05/1971 & 6.8 & $38.9 \mathrm{~N}-40.5 \mathrm{E}$ & Ilica & 35 & 0.25 & Arpat and Şaroğlu (1972) \\
\hline 24/01/2020 & 6.8 & $39.0 \mathrm{~N}-38.4 \mathrm{E}$ & Pütürge & 54 & not observed & \\
\hline
\end{tabular}





Figure 1. A: Tectonic map of the eastern Mediterranean and the Middle East. Arrows and numbers indicate the global positioning system (GPS)-derived velocities $\left(\mathrm{mm} \mathrm{yr}^{-1}\right)$ with respect to Eurasia (Reilinger and McClusky, 2011; Ergintav et al., 2014). EAFZ: East Anatolian Fault Zone; DSFZ: Dead Sea Fault Zone; BZATZ: Bitlis Zagros Active Thrust Zone; NAFZ: North Anatolian Fault Zone; RAE: Region of Aegean Extension. B: The map of the EAFZ between Karlıova (Bingöl) and Kahramanmaraş (Km) and the map of DSFZ between Kahramanmaraş and Antakya. The fault map is redrawn from Duman and Emre (2013). Please note that the DSFZ has been mapped as the Amanos Segment of the EAFZ in Duman and Emre (2013). The colored faults are the fault fragments that were ruptured during $\mathrm{Mw}>6.5$ earthquakes in the last 200 years. The colored numbers refer to years of the earthquakes that ruptured each fault. The earthquake data have been compiled from Ambraseys (1989), Guidoboni et al. (1994), Shebalin and Tatevossian (1997), Ambraseys and Jackson (1998), Kondorskaya and Ulomov (1999), Tan et al. (2008) and our study. For the review of the earthquake data see also Duman and Emre (2013). DSFZ: Dead Sea Fault Zone; Siv.: Sivrice. 

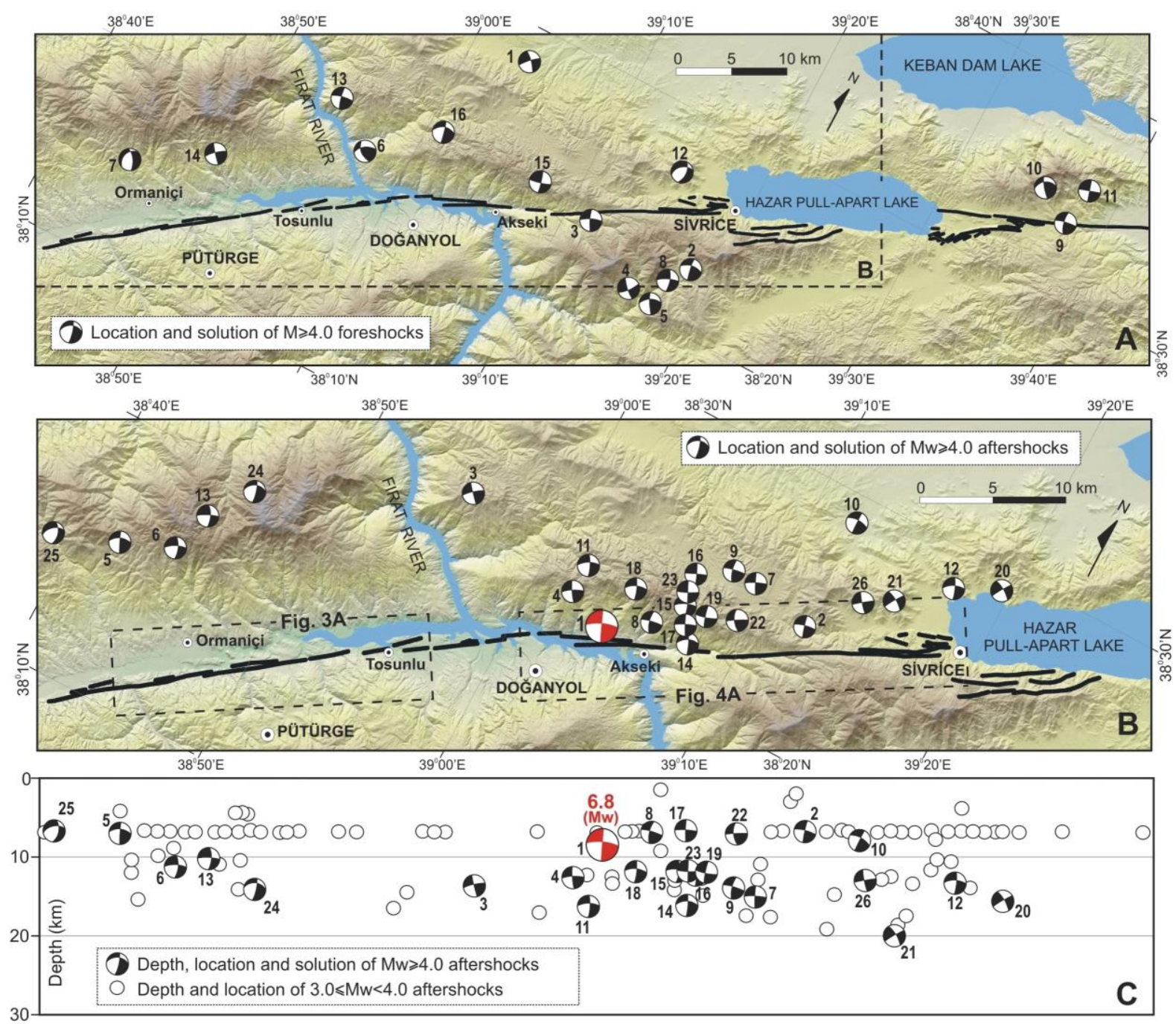

Figure 2. A: The map of the Pütürge Segment and the eastern part of the Palu Segment of the EAFZ, and the position-focal mechanism solutions of the $M \geq 4.0$ events that occurred before the 2020 earthquake (see also Table 1) shown over the Digital Elevation Model (DEM). The faults are redrawn from Duman and Emre, 2013. B: The position and the focal mechanism solutions of the 2020 earthquake (in red) and the $\mathrm{Mw} \geq 4.0$ aftershocks (see also Table 2) shown over the DEM. C: The depth and the location of the $\mathrm{Mw} \geq 3.0$ aftershocks. The solutions of the $\mathrm{Mw} \geq 4.0$ aftershocks are also shown (redrawn from AFAD database). 

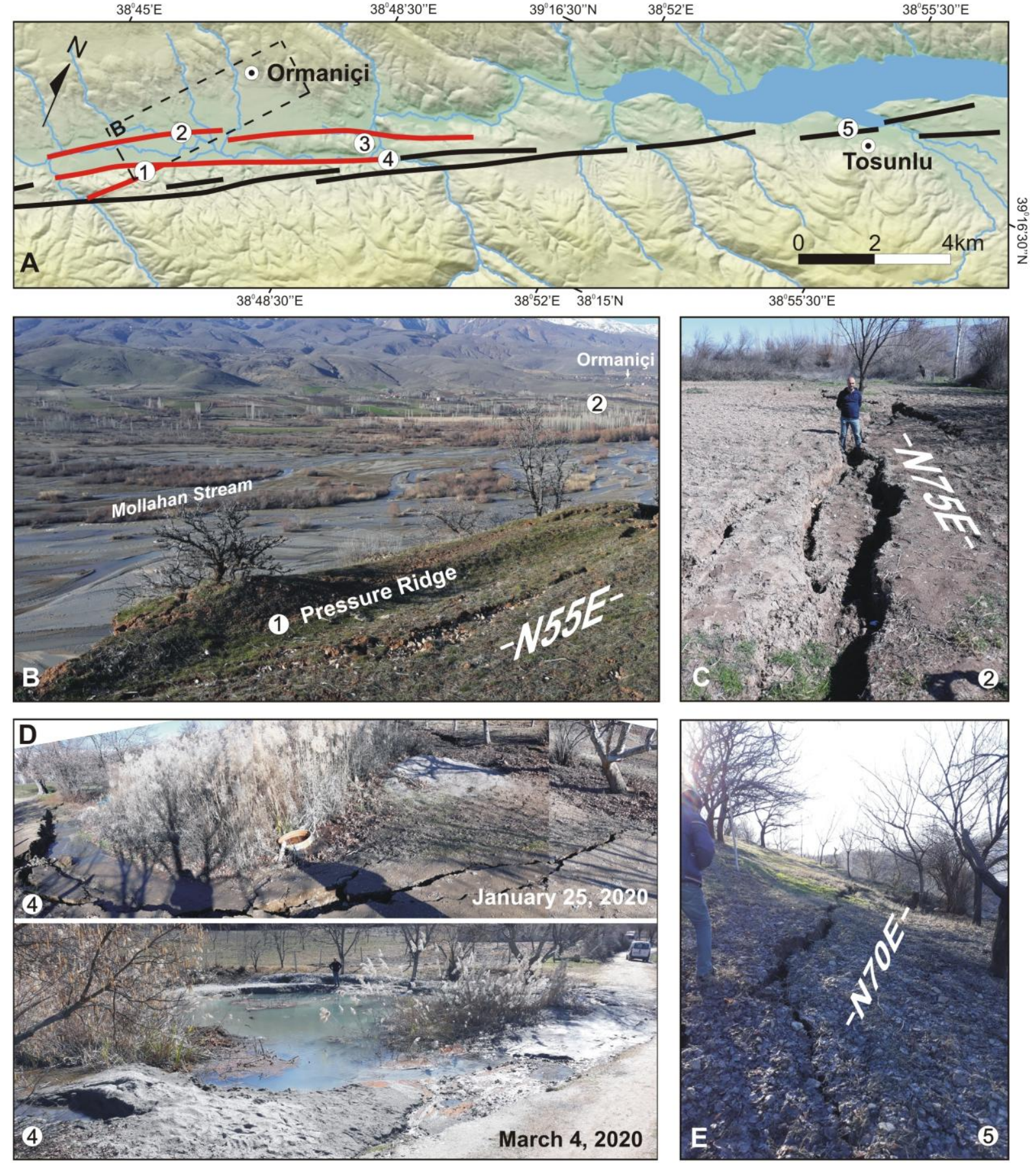

Figure 3. A: The active fault map of the Pütürge Segment between Ormaniçi and Tosunlu Villages and the position of the observed deformations (numbered). Black faults are from Duman and Emre (2013), the red faults are drawn during this study. B: The pressure ridge with extensive ground fissures formed during the 2020 earthquake, south of the Mollahan Stream. C: Deep-reaching ground fissures at the north of the Mollahan Stream. D: The liquefaction area at the east of Ormaniçi on 25 January 2020 (upper) and on 4 May 2020 (lower). E: An extensional, discontinuous ground fissure in Tosunlu Village. The numbers in figures are the location numbers shown in Figure 3A. See text and also Table 3 for the explanation. 



Figure 4. A: The active fault map of the Pütürge Segment between Doğanyol (Malatya) and Sivrice (Elazı $\breve{g}$ ) and the position of the observed deformations (numbered). Faults are from Duman and Emre (2013). B: The heavily damaged mosque in Sivrice. C: The photograph of the load-bearing columns of the Sivrice Mosque. Please pay attention to the lack of lateral reinforcement binders. D: A gravitational cracks with up to $40-50 \mathrm{~cm}$ downward movement. E: A surface crack that caused severe damage to telephone poles. F: The co-seismically formed pressure ridge south of the Çevrimtaş Village. The water body is the Karakaya Dam Lake that filled the Euphrates River Valley. G: The cracks formed over the pressure ridge with an average N80E direction. 


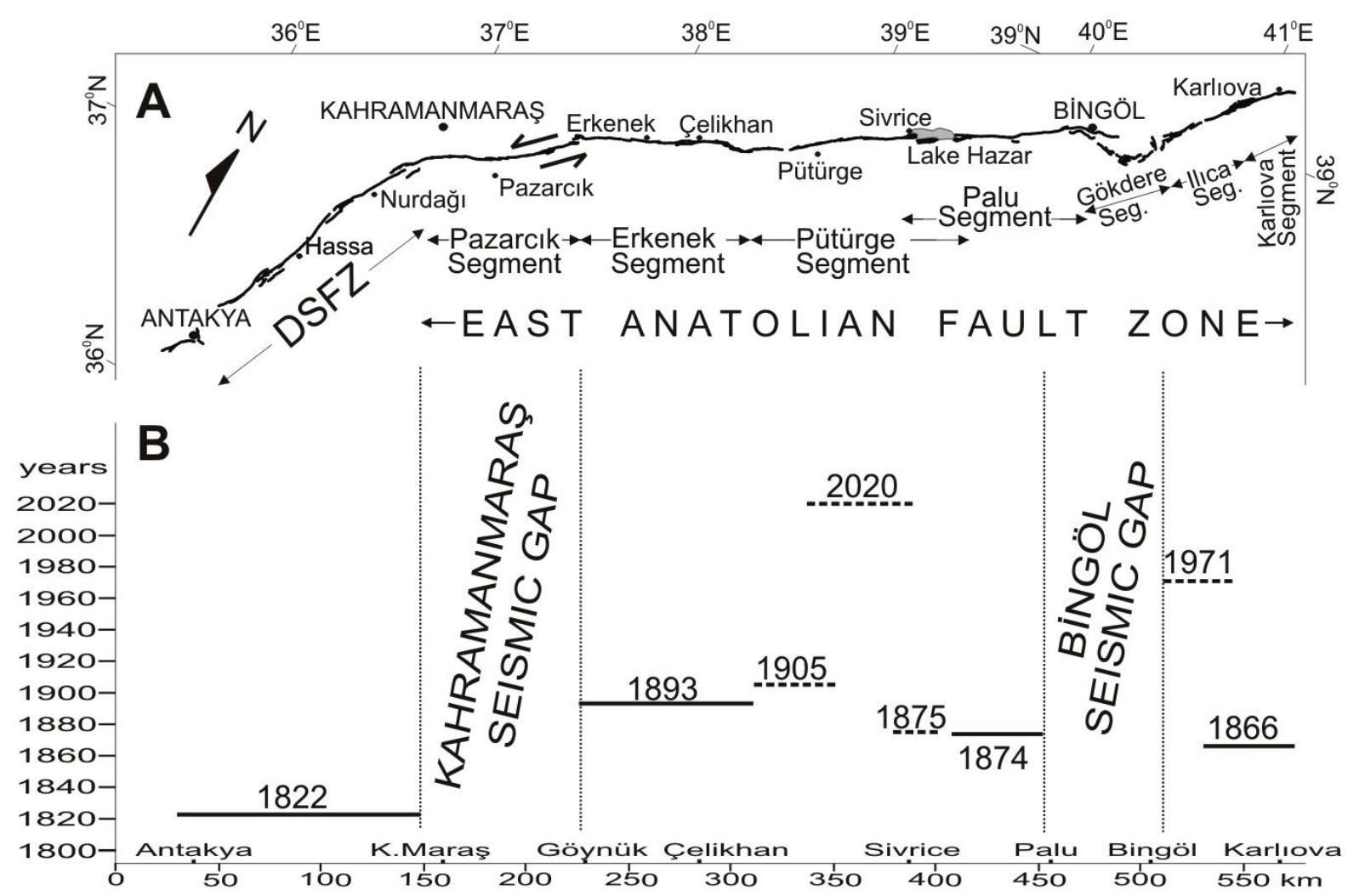

Figure 5. A: The map of the EAFZ between Karlıova (Bingöl) and Kahramanmaraş $(\mathrm{Km})$ and the map of DSFZ between Kahramanmaraş and Antakya. Fault map and segment names (accept DSFZ) are from Duman and Emre (2013). For the location of this figure see Fig. 1A. $\mathrm{B}$ : The rupture lengths vs rupture year of the major earthquakes $(6.3 \leq \mathrm{Ms} \leq 7.5)$ occurred along the EAFZ and the northern part of the DSFZ since the 1822. Those that caused formation of co-seismic surface slip are indicated with continuous lines. Those that were not caused formation of co-seismic surface slip are indicated with dashed lines. The earthquakes have been compiled from Ambraseys (1989), Guidoboni et al. (1994), Shebalin and Tatevossian (1997), Ambraseys and Jackson (1998), Kondorskaya and Ulomov (1999), Tan et al. (2008) and our study. For the review of the earthquake data see also Duman and Emre (2013). 


\section{Declaration of Interest Statement}

Editor

Tectonophysics

$8^{\text {th }}$ July 2020

Manuscript entitled «The surface deformation of the 2020 Doğanyol-Sivrice earthquake (Mw 6.8) and the earlier events suggest Mw<7.0 earthquakes do not create significant surface slip along the East Anatolian Fault Zone» submitted for consideration for publication in Tectonophysics.

Dear Sir/Madam,

We wish to confirm that there are no known conflicts of interest associated with this publication and there has been no significant financial support for this work that could have influenced its outcome.

We confirm that the manuscript has been read and approved by all named authors and that there are no other persons who satisfied the criteria for authorship but are not listed.

We further confirm that the order of authors listed in the manuscript has been approved by all of us.

We confirm that we have given due consideration to the protection of intellectual property associated with this work and that there are no impediments to publication, including the timing of publication, with respect to intellectual property. In so doing we confirm that we have followed the regulations of our institutions concerning intellectual property.

We understand that the Corresponding Author is the sole contact for the Editorial process (including Editorial Manager and direct communications with the office). He is responsible for communicating with the other authors about progress, submissions of revisions and final approval of proofs.

We confirm that we have provided a current, correct email address which is accessible by the Corresponding Author.

Signed by all authors as follows:

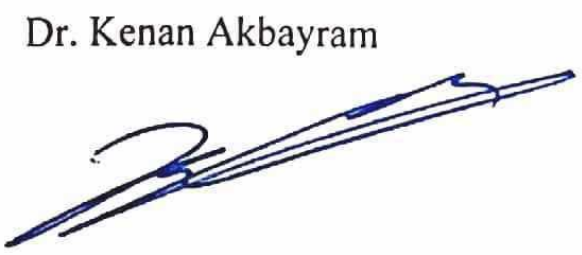

Dr. Çağlar Özer

Dr. Kemal Kıranşan
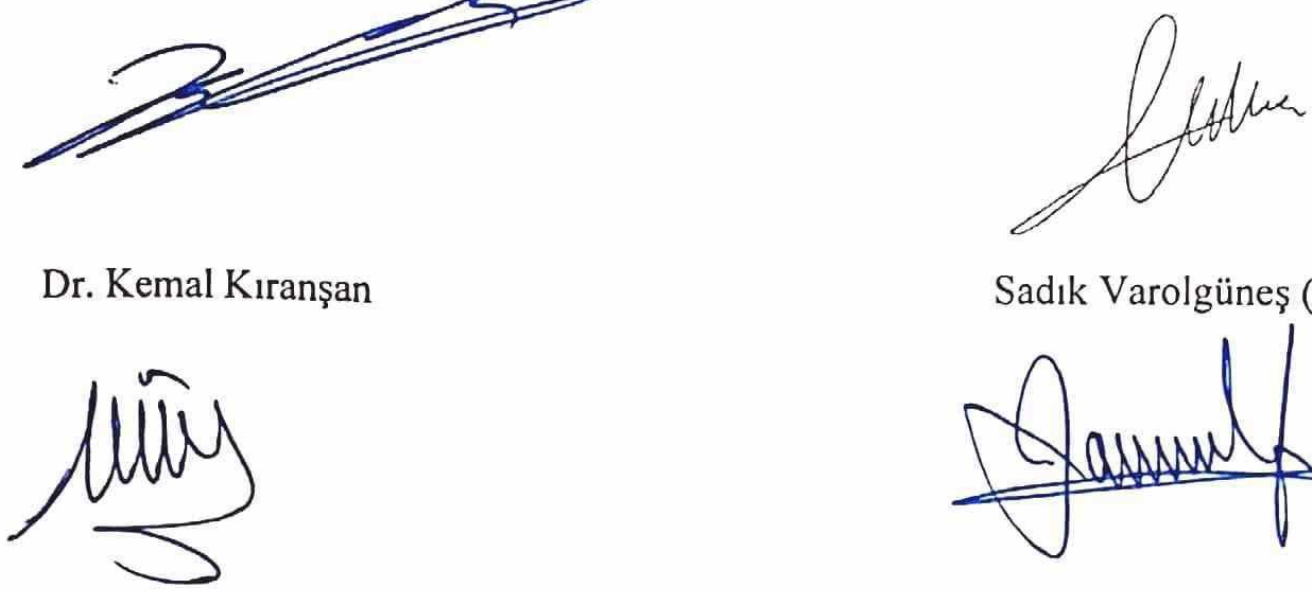

Sadık Varolgüneş (M.Sc.)

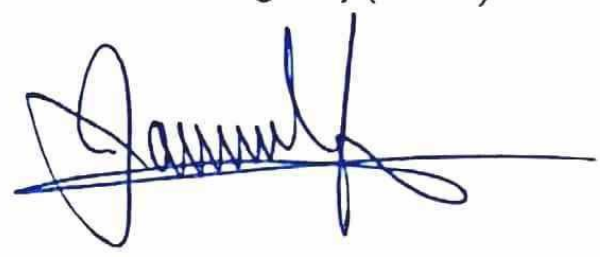

